Article

\title{
Authentic Historicality and National Socialism in Being and Time
}

Saurabh Todariya

\begin{abstract}
This paper will explore 'Heidegger's controversy,' which has perplexed the scholars for a long time. We need to see whether we can distinguish Heidegger, 'the philosopher' from Heidegger 'the Nazi.' I would like to suggest that the notion of Geschistlichkeit in Being and Time shows the intimate connections between the fundamental ontology of Dasein and Heidegger's sympathy for National Socialism. The paper will argue that the analysis of 'authentic historicality' in Being and Times shows the link between the authenticity of Dasein and Heidegger's involvement with National Socialism.
\end{abstract}

Keywords: Dasein, Geschistlichkeit, historicality, repetition

\section{Introduction}

"H eidegger Controversy" remains a perplexing issue for any scholar who deals with the thoughts of Martin Heidegger. This is so because Heidegger's life shows us a confounding combination of profound philosophical thoughts and questionable political conduct. Heidegger's brief engagement with National Socialism during Second World War and his subsequent silence about the issue have baffled the thinkers. 'Heidegger Controversy' fueled up this year again after the publication of the controversial Black Notebooks. Heidegger Chair in Freiburg University resigned on the moral ground, citing its allegedly anti-Semitic content. Ever since Heidegger's involvement with National Socialism, scholars heatedly debated his involvement with the ideology of National Socialism. On the one hand, there are thinkers like Theodor Adorno, Jurgen Habermas, Emmanuel Levinas, and Herbert Marcuse who argue that there is a direct connection between Heidegger's philosophy and his conservative political thoughts. ${ }^{1}$ On the other hand, scholars like Hannah Arendt, Richard

${ }^{1}$ Adorno establishes the relationship between Heidegger's political leanings and the philosophical concepts in Being and Time. He argues that Heidegger's emphasis on authenticity

(c) 2016 Saurabh Todariya http://www.kritike.org/journal/issue 18/todariya june2016.pdf ISSN 1908-7330 
Rorty, and Jacques Derrida argue that we cannot reduce Heidegger's philosophical thoughts to his conservative political opinions and his brief engagement with National Socialism should be seen as a 'folly' on the part of the thinker who tried to involve in the political realm. We, therefore, need to differentiate or even salvage Heidegger's thinking from his occasional political pitfalls. ${ }^{2}$

Heidegger's sustained silence on this issue and his provocative statement regarding the holocaust of Jews later in Question concerning the Essence of Technology further complicates the matter. Given the complex and controversial nature of the problem, the present paper will take the moderate position regarding the "Heidegger Controversy." I will try to show that although Heidegger's thoughts cannot be legitimately reduced into the Nazi ideology; nevertheless, the fundamental ontology of Dasein in Being and Time does have the political aim which could be churned out from the analysis of authentic historicality. Hence, we cannot discard Heidegger's involvement with National Socialism as an aberration of a philosopher. His support for National Socialism stems from his philosophical ideas, which are very clearly evident in his infamous Rector Speech, along with works like Being and Truth, Introduction to Metaphysics, and Black Notebooks. He saw National Socialism as a historical possibility, which can make German people authentic. To comprehend the connection between his philosophical and political ideas, we need to analyze his notion of 'authentic historicality' in Being and Time. On the basis of this analysis, we shall argue that the notion of co-historicality and destiny does have the basis of a strong and exclusive community, which can overcome the pitfalls of everydayness and can realize its historical essence.

\section{Historicality and Care}

Heidegger's analysis of temporality in Being and Time finally

is basically a political category than a formal concept. See Theodor Adorno, Jargon of Authenticity, trans. by Knut Tarnowski and Frederic Will (Evanston: Northwestern University Press, 1973).

Habermas's take on Heidegger's Introduction to Metaphysics in Jurgen Habermas, "Martin Heidegger: On the Publication of the Lectures of 1935," trans. by William S. Lewis, in The Heidegger Controversy: A Critical Reader (Cambridge: The MIT Press, 1993), 186-197.

Levinas takes Heidegger to task for not taking the question of the 'Other' into consideration. See Emmanuel Levinas, Totality and Infinity, trans. by Alpohnso Lingis (Hague: Martinus Nijhoff Publishers, 1969).

2 Hannah Arendt uses Heidegger's notion of 'thinking' in relationship with the moral responsibility. See Hannah Arendt, Responsibility and Judgment (New York: Schocken Books, 2003).

Jacques Derrida delves into Heidegger's relationship with National Socialism by taking up the question of Spirit in Heidegger. See Jacques Derrida, Of Spirit: Heidegger and the Question, trans. by Geoffrey Benington and Rachel Bowlby (Chicago: The University of Chicago Press, 1989).

(c) 2016 Saurabh Todariya

http://www.kritike.org/journal/issue 18/todariya june2016.pdf

ISSN 1908-7330 


\section{AUTHENTIC HISTORICALITY AND NATIONAL SOCIALISM}

culminates in the notion of Geschistlichkeit or Historicality. ${ }^{3}$ Historicality is a technical term, which Heidegger defines in terms of fundamental ontology of Dasein. In the earlier sections of Being and Time, Heidegger argues that the ontology of Dasein should be understood with respect to temporality. Heidegger defines the being of Dasein in terms of Care structure. ${ }^{4}$ Care is the structural unity, which defines the existence of man as being-in-the-world. The specific component of Care is 'ahead-of-itself.' 5 This structure of care as 'ahead-of-itself' specifically comes into picture when Heidegger discusses anxiety as fundamental attunement. Heidegger brings in the issue of Care in Being and Time after the discussion of anxiety. ${ }^{6}$ Anxiety is a specific type of disclosure, which individuates Dasein. It makes possible for Dasein to become authentic. ${ }^{7}$ In this way, Dasein realizes itself as the possible. According to Heidegger, Dasein's basic structure as possibility is because Dasein is fundamentally 'ahead-of-itself.' The 'ahead-of-itself' has to be seen in Dasein's specific relationship with Death. Death is the non-relational possibility which individuates Dasein and it projects itself as 'ahead of itself' in anticipation of 'running its course,' which Heidegger calls as Vorlaufenheit. ${ }^{8}$

Dasein is an entity for which, in its Being, that Being is an issue. The phrase 'is an issue' has been made plain in the state-of-being of understanding-of understanding as self-projective Being towards its ownmost potentialityfor-being. This potentiality is that for the sake of which any Dasein is as it is ... ontologically, Being towards one's ownmost potentiality-for-Being means that in each case Dasein is always 'beyond itself' ... as Being towards the potentiality-for-Being which it is itself. This structure of Being, which belongs to the essential 'is an issue,' we shall denote as Dasein's Being-ahead-of-itself. ${ }^{9}$

'Being-ahead-of-itself' points towards the most fundamental

${ }^{3}$ Martin Heidegger, Being and Time, trans. by John Macquarrie and Edward Robinson (New York: Harper and Row, 1962), 424.

${ }^{4}$ Ibid., 227.

${ }^{5}$ Ibid., 236.

${ }^{6}$ Ibid., 228.

${ }^{7}$ Heidegger defines anxiety as a distinctive way in which Dasein is disclosed. See Heidegger, Being and Time, 228.

${ }^{8}$ According to Heidegger, Dasein's being is constituted by the 'not yet' because of its relationship with death. Hence, it projects itself as 'ahead-of-itself' while 'running its course' (Vorlaufenheit). By including 'ahead-of-itself' in care structure of Dasein, Heidegger defines the existence of Dasein in terms of possibility. See Heidegger, Being and Time, 287.

${ }^{9}$ Ibid., 236.

(c) 2016 Saurabh Todariya

http://www.kritike.org/journal/issue 18/todariya june2016.pdf

ISSN 1908-7330

(c) BY-NC-ND 
constituent of Dasein. Dasein is the only entity for whom its own being is an issue; this is because it involves 'ahead-of-itself' in the care structure. That is why anxiety becomes a specific kind of disclosure for Dasein in which it realizes itself as 'possibility.' However, the 'ahead-of-itself' is not some kind of exceptional capacity of Dasein; rather, it is the part of Dasein's facticity as Heidegger defines it as "ahead-of-itself-in-already-being-in-a-world." In his words, 'existentiality is essentially determined by facticity. ${ }^{10}$ Heidegger tries to show that the ontological constituent of Dasein as 'ahead-of-itself' can only be grasped through taking the issue of temporality into account. Dasein can be 'ahead-of-itself' because there is primacy of future in temporality. Hence, Care is basically temporal in nature. Temporality reveals itself as the meaning of authentic care. ${ }^{11}$

Care structure is the unity of the past, present, and future. However, the past, present, and future are not used as mere modifications of time; rather, they are defined in existential manner. Heidegger does not simply mean that existence is temporal as it would have been naïve and commonsensical. To be human means to exist in time. It is true not only for humans but also for any other existing living forms. We cannot think of any form of existence which is independent of time. Heidegger, however, gives twist to this commonsensical understanding of time by calling it temporality. Temporality is the way in which human existence relates itself to time. Heidegger defines human existence as Care in order to show the relationship between human existence and time. However, this relation is possible only by understanding time in an ontological manner. In Care structure, time has been described as an ecstatic unity of the past, present, and future, which has the primacy of the future. According to Heidegger, it is only the future which gives unity to the past, present, along with future. He says that, "The primary phenomena of primordial and authentic temporality is the future." 12

Heidegger's notion of temporality rejects the ordinary understanding of time in which the primacy is accorded to the present. In ordinary understanding of time, the past and the future are defined as no longer now and the upcoming now. Hence, the past and the future become the modifications of present. Heidegger, on the other hand, argues that in order to grasp the real essence of time, we need to understand time as ecstatic temporality. In ecstatic temporality, time is not understood as separate moments of the past, present, and future; rather, time is understood in terms of its unity of the past, present, and future. Here we need to understand what Heidegger means by the term 'unity.' It is not just adding up of the three moments of time together. The unity is basically ecstatic in nature in which

\footnotetext{
${ }^{10}$ Ibid.

${ }^{11}$ Ibid., 374.

${ }^{12} \mathrm{Ibid} ., 378$
}

(c) 2016 Saurabh Todariya

http://www.kritike.org/journal/issue 18/todariya june2016.pdf

ISSN 1908-7330 
each moment becomes itself only by flowing outside itself. According to Heidegger, unity of time should be located in the care structure of Dasein. Time flows from the future to the past and then to the present.

Temporality makes possible the unity of existence, facticity, and falling, and in this way constitutes primordially the totality of the structure of care. The items of care have not been pieced together cumulatively any more than the temporality itself has been put together 'in the course of time' out of the future, the having been and the Present. Temporality 'is' not an entity at all ... it temporalizes itself ... Temporality is the primordial 'outside-of-itself' in and for itself. We therefore call the phenomena of the future, the character of having-been, and the Present, the "ecstases" of temporality ... its essence is a process of temporalizing in the unity of the ecstases. ${ }^{13}$

Of all entities, Dasein alone has relationship with the future, which Heidegger defines as 'being-ahead-of-itself.' However, the projection of the future is possible only through the ecstatic or its inherent unity with the present and the future, which makes possible the phenomena of temporality for humans. The projection towards the future brings Dasein to its facticity, to its past; hence, only on the basis of the future and the past, it comes to have the present as present. Hence, the present is not an isolated patch but is stitched to the past and flows towards the future. Heidegger, therefore, comes out of the abstract or formal notion of time by making it as the very ground on which humans interpret themselves. The $D a$ of Dasein, its 'beingthere,' is disclosed to Dasein because it is temporal in nature. The 'there-ness' of Dasein as the facticity, falleness, and projection is possible on the basis of ecstatic temporality of Dasein. The world is disclosed to Dasein as the network of possibilities because of the ecstatic unity of the past, present, and future.

The temporal analysis of Dasein brings Heidegger to the problematic of history. Since we do not relate to time in abstract manner but in existential way, the question of history becomes of paramount importance. According to Heidegger, History should be understood in relationship with temporality. ${ }^{14}$

\footnotetext{
${ }^{13}$ Ibid., 376-77.

${ }^{14}$ In analyzing the historicality of Dasein, we shall try to show that this entity is not 'temporal' because it 'stands in history,' but that, on the contrary, it exists historically and can so exist only because it is temporal in the very basis of its Being. See Heidegger, Being and Time, 428.

(c) 2016 Saurabh Todariya http://www.kritike.org/journal/issue 18/todariya june2016.pdf

ISSN 1908-7330
}

(cc) BY-NC-ND 
In Being and Time, Heidegger starts from the common understanding of 'past' in which past has been interpreted in terms of bygone, elapsed, which is no longer present now. We call such past as dead. ${ }^{15}$ This notion of past is based on the understanding of past as the modification of the present. The past as such does not have any ontological status; its being is dependent on the present. When a present moment passes away, the past comes into existence. Heidegger questions such an understanding of past and tries to understand past in its own terms. Humans never relate to the past as bygone or dead; rather, for them the past is conceived in terms of tradition which affects them. Therefore, they interpret themselves in terms of the past. Bernard Stiegler elaborates this point in Time and Technics wherein he argues that the notion of historicality in Heidegger should be understood in terms of the non-lived past of the ancestors which 'affects' individuals.

Dasein is temporal: it has a past on the basis of which it can anticipate and thereby be. Inherited, this past is "historical": my past is not my past; it is first that of my ancestors, although it is in essential relation with the heritage of a past already there before me that my own past is established. This historical, non-lived past can be inherited inauthentically: historicality is also a facticity. The past harbors possibilities that Dasein may not inherit as possibilities. The facticity implied by heritage opens up a twofold possibility for self-understanding. On the one hand, Dasein can comprehend itself on the basis of an understanding of existence which is banal and "opining" (subject to everyday opinion). On the other hand, Dasein can "possibilize" this past, in that it is not its own, insofar it has inherited it: it is then on the basis of its possibility - such that its past is constituted therein - that it inherits possibilities of "its" factical past. Dasein is in the mode of "having-to-be" because it never yet totally is; inasmuch as it exists, it is never finished, it always already anticipates itself in the mode of "not yet." Between birth and death, existence is what extends itself [Er-streckung] between "already" and "not yet."16

Heidegger calls the understanding of past in terms of bygone or no longer as inauthentic historicality. It understands past as the modification of

15 Ibid., 430.

16 Bernard Stiegler, Technics and Time, vol. 1, trans. by Richard Beardsworth and George Collins (Stanford California: Stanford University Press, 1998),5.

(c) 2016 Saurabh Todariya

http://www.kritike.org/journal/issue 18/todariya june2016.pdf

ISSN 1908-7330

(cc) BY-NC-ND 


\section{AUTHENTIC HISTORICALITY AND NATIONAL SOCIALISM}

present. Historians study past in this way when they study fossils, artifacts, or antique objects. These objects used to be the part of some civilization but now they are no longer part of the present. Hence, they are called past or antique objects. According to Heidegger, such an understanding of past does not deal with the fundamental question of why history is important for humans. History cannot be reduced to a discipline in which we study the past. Rather, we need to analyze the question of what history has got to do with the human existence. The objects do not become historical only because they are old and outdated; rather, they become historical because through them, the life-world of the earlier generation shows itself. Hence, the past can be properly grasped through understanding its relationship with human existence. Heidegger argues that we can understand history in an authentic manner by relating it with the care structure of Dasein, which shows the relationship between history and temporality. Heidegger calls this basic relation between history and temporality 'Historicality.'

Disclosing and interpreting belong essentially to Dasein's historizing. Out of this kind of Being of the entity which exists historically, there arises the existentiell possibility of disclosing history explicitly and getting it in our grasp. The fact that we can make history our theme - that is to say, disclose it historiologicallyisthe presupposition for the possibility of the way one builds up the historical world in the human sciences. ${ }^{17}$

According to Heidegger, historicality belongs to the fundamental nature of Dasein. It is because of the historicality of Dasein that history, as such, has become the issue for it. We do not relate to past as simply gone and lost in the time. Rather, past is interpreted as 'having been.' According to Paul Ricouer, Heidegger differentiates between two kinds of pasts. One past is that with which historiographer deals with; another past is what Heidegger calls as 'having-been' and belongs to our existence as 'care.'18 This 'having been' of the past is possible because of the care structure of Dasein, which involves the primacy of the future. Only because Dasein is futural in its constitution can it have the past.

The past is not a present time that has passed by; rather, the past's being is set free only through its state of having been. The past reveals itself as that definitive state of

${ }^{17}$ Heidegger, Being and Time, 428.

18 Paul Ricouer, Time and Narrative, vol. 3, trans. by Kathleen Blamey and David Pellauer (Chicago: The University of Chicago Press, 1988), 351.

(c) 2016 Saurabh Todariya http://www.kritike.org/journal/issue 18/todariya june2016.pdf ISSN 1908-7330

(c) BY-NC-ND 
one's having been that is characteristic of futuralness, a futuralness which one resolves to embrace through grappling with the past. Authentic historicity is not a matter of presencing something, but that state of being futural in which one readies oneself to receive the right impetus from the past in order to open it up. In such futuralness histriological investigation enters the present; it becomes the critique of the present. ${ }^{19}$

Heidegger, therefore, is not interested in history as a discipline; rather, his problem is why history does matter to humans and how they relate to it. According to him, only when Dasein tries to live authentically does the past become the storehouse of possibilities. Hence, the past becomes a living past only with reference to the question of authenticity.

According to Heidegger, the authentic historicality for a Dasein can only be possible when it finds out its authentic existence by pulling itself out of Dasman, they. "They" or Dasman is the term Heidegger uses for the 'average, public understanding.' 20 'They' provides average possibilities for a Dasein to behave and think according to the prevalent social norms. Dasein's average behavior remains dominated by Dasman. It is the general understanding or the intersubjectivity, which guides and controls the individual values and choices. According to Heidegger, although such an understanding is our ontological characteristic, it also makes us forget the most important ontological question- "What does it mean to be?" Only when the average everyday world of absorption in activities gets suspended in the rare mood of 'anxiety' can we ask this question. ${ }^{21}$

The task of fundamental ontology in Being and Time, therefore, is twofold; first, to analyze the humans in their average, public mode; second, to explore the true meaning of existence other than the public mode of existence. In the second division of Being and Time, the question of death, authenticity, resoluteness, and historicality is discussed with regard to the meaning of existence. The second division takes up the question of authenticity in the face of Death.

However, we need to understand that for Heidegger, death does not mean the physical death but the awareness of one's own finitude. The analysis of death shows that Dasein becomes aware of its facticity. Dasein realizes its 'mineness' only when it is delivered to its finitude in the face of its

${ }^{19}$ Heidegger, Being and Time, 80.

${ }^{20}$ Ibid.,164.

${ }^{21}$ Heidegger defines anxiety as a specific type of disclosure as it individuates Dasein and makes manifest to it that authenticity and inauthenticity are possibilities of its Being. See Heidegger, Being and Time, 235.

(c) 2016 Saurabh Todariya http://www.kritike.org/journal/issue 18/todariya june2016.pdf ISSN 1908-7330 


\section{AUTHENTIC HISTORICALITY AND NATIONAL SOCIALISM}

inescapable mortality. Dasein either lulls itself again into the average public life, being unable to face its individuation, or it may gather itself and become resolute. This resoluteness, however, should not be confused as the 'resolve' to do something. It is not some practical action; rather, this is the ontological mode in which Dasein becomes ready to own up oneself, which is the actual meaning of being authentic, Eigentlichkleit.

While Heidegger defines resoluteness mostly in abstract terms, in the sections on historicality, he explains the resoluteness as Repetition. ${ }^{22}$ Resolute Dasein does not become a transcendental entity but realizes the truth of its existence in terms of its falleness. It cannot dispense with its facticity, its historicity. The being of Dasein is inextricably woven with the historicity to which it belongs. When it becomes resolute, it chooses the past possibilities which have not been realized. In this way, he 'repeats' the possibilities latent in the tradition by not simply reproducing them but repeating them with the futural projection. This is what Heidegger means by 'authentic historicality.' Only by relating with history in an authentic manner does Dasein become authentic.

Heidegger, therefore, introduces the notion of "Repetition" in the context of the authentic Historicality. The notion of Repetition becomes crucial as it links Dasein's resoluteness to the historical possibilities. According to Heidegger, Repeating is going back into the possibilities of the Dasein that has-been-there. Repetition, accordingly, is not a matter of making actual again what has been previously actualized. Therefore, it is not reduplication of a previous act. In Heidegger's words, Repetition is not 'bringing back again' what is the old.

But when one has, by Repetition, handed down to oneself a possibility that has been there, the Dasein that has-been-there is not disclosed in order to be actualized over again. The repeating of that which is possible does not bring back again something that is 'past,' nor does it bind the 'present' back to that which has already been outstripped. Arising, as it does, from a resolute projection of oneself, Repetition does not let itself be persuaded of something by what is "past," just in order that it, as something which was formerly actual, may recur. ${ }^{23}$

\footnotetext{
${ }^{22}$ Heidegger says, "the resoluteness which comes back to itself and hands itself down, then becomes the Repetition of a possibility of existence that has come down to us." See Heidegger, Being and Time, 437.

${ }^{23}$ Ibid., 437-38.

(c) 2016 Saurabh Todariya http://www.kritike.org/journal/issue 18/todariya june2016.pdf ISSN 1908-7330
}

(c) BY-NC-ND 
Since the being of Dasein has been defined as possibility, Repetition is always focused on the possible. Dasein is authentically itself inasmuch as it projectively anticipates the possible. The simple reduplication which reproduces something already actualized is precisely a movement away from the origin, precisely the de-generation which is the source of the inauthentic, the second-hand, the fallen. Repetition is always an originary operation by means of which Dasein opens up possibilities latent in the tradition, bringing forth something new. ${ }^{24}$ In Repetition, Dasein is productive of what it repeats; it does not simply go over old ground. The self produces itself by Repetition. In Repetition, Dasein discloses its own being and that of the historical situation in which it belongs. Repetition is a first, a breakthrough, a retrieval which pushes forward, which opens what was previously closed and held in check. Repetition is a new beginning, which aims at the possible. ${ }^{25}$

\section{Heidegger and Politics}

The notion of authentic historicality is intimately connected with the issue of Resoluteness in Being and Time. Resoluteness results from the readiness of Dasein to face anxiety, which is its fundamental attunement. Only in the readiness to face anxiety does Dasein become resolute. Resolution should not be understood as the psychological capacity. As Heidegger defines resoluteness as the 'readiness to become anxious', we need to see the connection between resoluteness and anxiety.

According to Heidegger, in the mood of anxiety, what is environmentally ready-to-hand sinks away and entities in the world lose their significance. The 'world' could offer nothing more in the form of 'present-to-hand' and 'ready-at-hand' and nor can the Dasein-with of Others. Anxiety, thus, takes away from Dasein the possibility of understanding itself in terms of the 'world' and the way things have been publicly interpreted.

${ }^{24}$ In Jacques Derrida's deconstruction can be seen the extension of Heidegger's Repetition. John Caputo makes the interesting comparison between Derrida's deconstruction and Heidegger's Repetition. See John Caputo, Radical Hermeneutics: Repetition, Deconstruction and the Hermeneutics (Bloomington: Indiana University Press, 1987).

${ }^{25}$ John Caputo defines Repetition in the sense of Deconstruction which dismantles the past. "Repetition 'answers' what is calling to it in what has been, 'responds' to what is possible, makes a 'rejoinder' which consists in bringing forth something for which Dasein has up to now only obscurely groped. The rejoinder (Erwiderung) is a rebuff (Widerruf) of the inertial weight of the past. It is a living response which speaks against, protests, disavows the weight of a tradition which has become leaden and lifeless; effecting the possible is 'revolutionary,' while clinging to the past is conservative. There is thus a deconstructive moment in Repetition, a moment of counter-movement, of rebuttal ... Repetition aims at not the actual but the possible." Caputo, Radical Hermeneutics: Repetition, Deconstruction and the Hermeneutics, 91.

(c) 2016 Saurabh Todariya

http://www.kritike.org/journal/issue 18/todariya june2016.pdf

ISSN 1908-7330

(cc) BY-NC-ND 


\section{AUTHENTIC HISTORICALITY AND NATIONAL SOCIALISM}

Anxiety, hence, makes impossible any comportment towards the world either as present-to-hand or ready-to-hand. ${ }^{26}$

Heidegger links the concept of 'Nothing' with anxiety in order to show the groundlessness of the human existence. In anxiety, Dasein faces the Nothing. Nothing is encountered as its own finitude. It realizes that 'nothing,' which is available in the everyday world of Dasman, can ground its existence. Dasein realizes that nothing but only it grounds its own existence. It gives meaning to life and there is no meaning independent of its existence. This makes Dasein resolute, and it 'owns up' its existence, which is called 'being authentic' by Heidegger. That is why Heidegger says that in anxiety, Dasein realizes that 'it is the null basis of its nullity.' ${ }^{27}$

The issue of Repetition is intimately linked with the question of authenticity. Only an authentic Dasein can repeat. For an inauthentic Dasein, there would be no anxiety or resoluteness; hence, it cannot repeat. Heidegger's account of Repetition therefore calls for the productive relationship with the past in which one dismantles the past in order to show up the possibilities inherent in it. ${ }^{28}$ The hermeneutic engagement with the past enables one to dismantle the fossilized structures and contexts of the past and to see the past in terms of possibility. The source of this productive relationship with the past has to be located in the ontological structure of Dasein who relates with the past with reference to its existence.

However, what problematizes or at least questions the 'deconstructive Heidegger'29 are the notion of 'destiny,' 'people,' and 'cohistorizing' in his account of authentic historicality. These notions show us the conservative aspect of Heidegger's philosophy and force us to see the relationship with Heidegger's philosophical ideas and his sympathy for National Socialism. I will therefore try to show that the 'Authentic historicality' does involve Heidegger's passion for the German fatherland and National Socialism.

${ }^{26}$ However, the absence of comportment does not point towards solipsism; on the contrary, in anxiety Dasein realizes its fundamental situation of 'being there.' Heidegger makes it clear, "The utter insignificance which makes itself known in the "nothing and nowhere," does not signify that the world is absent, but tells us that the entities within-the-world are of so little importance in themselves that on the basis of this insignificance of what is within-the-world, the world in its world-hood is all that still obtrudes itself." See Heidegger, Being and Time, 231.

27 Ibid., 330-31.

${ }^{28}$ Dana Villa compares the notion of Repetition in Heidegger and Walter Benjamin by analyzing it in relationship with the past. See Dana Villa, Arendt and Heidegger: The Fate of the Political (Princeton: Princeton University Press, 1996).

${ }^{29}$ The deconstructive or radical nature of Heidegger's thinking is argued by Caputo. Caputo argues that Heidegger's notion of destruction dismantles the fossilized and rigid structures of tradition. See Caputo, Radical Hermeneutics: Repetition, Deconstruction and the Hermeneutics.

(c) 2016 Saurabh Todariya

http://www.kritike.org/journal/issue 18/todariya june2016.pdf

ISSN 1908-7330

(cc) BY-NC-ND 
What distinguishes Heidegger's analysis of resoluteness from other existentialist thinkers is the concept of fate, which he makes an essential ally of resolution. ${ }^{30}$ Unlike Sartre and other existentialist thinkers who make 'choice' essential for the authentic existence, Heidegger defines resoluteness as 'giving up' some definite resolution in accordance with the demands of Situation. ${ }^{31}$

Resoluteness cannot be interpreted as autonomy. Heidegger's account of resoluteness should not be mistaken as being resolute to start a new course of action, which is not available in the everyday world of Dasman. For an authentic Dasein, the past is replete with the possibilities. However, it does not mean that Dasein can make a random choice out of sheer caprice; rather, in authenticity, Dasein comes to face its 'there'; it realizes that it has been thrown into the facticity or the historical situation which it cannot avoid. This is what Heidegger means by 'fate.' Hence, being resolute, Dasein gives itself up to fate. Hence, it discovers not some abstract freedom but a kind of situated freedom in the specific historical context. ${ }^{32}$

Authentic Dasein sees the past as heritage; it does not forget the past in the chattering of They. It realizes itself as a part of the community. Its fate is inextricably interwoven with the fate of the community. Paul Ricouer defines the notion of Repetition as the link between the individual and the collective history. According to Ricouer, there is aporia in phenomenology between the lived time of an individual and the historical time of the ancestors. Only through the 'narrativity' in the form of stories or myths is the individual able to own up the past of ancestors. ${ }^{33}$ Through the various narrations in the form of myths and traditions, the lived time of the ancestors becomes a part of the historicity of Dasein. Hence, we can argue that through the concept of Repetition, fundamental ontology makes transition to historicity. In inauthentic mode, Dasein is a part of They. He acts and behaves as the everyday structure of Dasman requires of him. Only when he individualizes himself in the face of death does he discover the truth about its existence. As he says, in anxiety Dasein discovers its 'thereness.' The truth

\footnotetext{
${ }^{30}$ Heidegger defines fate in terms of the 'finitude of one's existence.' See Heidegger, Being and Time, 435.

31 Heidegger defines Situation as 'something which cannot be calculated in advance.' See Heidegger, Being and Time, 355.

${ }^{32}$ Throughout the explanation of Care in Being and Time, Heidegger interprets Freedom as a kind of making choice in a specific situation. He defines Care structure as 'being-ahead-ofitself-being-in-the-world'. See Heidegger, Being and Time, 236.

${ }_{33}$ Paul Ricouer tries to establish the relationship between the individual past and the ancestral past through the concept of narrativity. He writes, "In this way, a bridge is constructed between the historical past and memory by the ancestral narrative that serves as a relay station for memory directed to the historical past, conceived of as the time of people now dead and the time before my death." See Ricouer, Time and Narrative, vol. 3, 114.
}

(c) 2016 Saurabh Todariya http://www.kritike.org/journal/issue 18/todariya june2016.pdf ISSN 1908-7330 


\section{AUTHENTIC HISTORICALITY AND NATIONAL SOCIALISM}

about his existence is his throwness and facticity. He becomes truly historical when he realizes that the past is an inalienable part of his existence. However, this past not only belongs to him and his lived experiences but also includes the past of the ancestors, which is the past of the community. Hence, fate and destiny are interlinked with each other. That is why, for an authentic Dasein, the question of existence involves a historical choice where he has to choose not only for himself but also for his community.

Therefore, the analysis of ontology in Being and Time ultimately boils down to the question of making a historical choice for one's community. This makes the analysis of fundamental ontology inherently political. Hence, the concept of Repetition is basically political in nature. Dasein stands in history where it sees itself involved in the historical current, which is its fate, and it responds authentically to its facticity by repeating the possibilities from the collective past by which its community can realize its true essence.

The relationship between Heidegger's thoughts and National Socialism can therefore be analyzed through the notion of Historicality, which shows the deep connections between his political views and philosophical ideas. Heidegger invokes the community in his political speeches. One of the most controversial of Heidegger's acts is his taking up the Rector's position in Freiburg University in 1933. In his notorious Rectoral Speech, "The Self Assertion of the German University," he almost speaks up like a Nazi ideologue who is urging his countrymen to work for the Fuhrer. ${ }^{34}$ What is more striking is that the various terminologies used by Heidegger in his Rectoral address have been already deployed in Being and Time. Terms like 'Volk,' 'Destiny,, 'History,, 'Spirit,' 'Resoluteness,' and 'Strife' were freely used in connection with the spiritual mission of the German nation. The interesting aspect is that Heidegger urges the students to fulfill the historical mission, which is reserved for the German nation as only it only has the spiritual strength to guide the world. He says, "But it is our will that our Volk fulfills its historical mission." 35

In this regard, it is important to take up the issue of Black Notebooks which again fueled up the Heidegger controversy. Black Notebooks reveals the deep connection between Heidegger's philosophy and his anti-Semitism. It is not the case that the controversy regarding Black Notebooks conclusively proves Heidegger's involvement with National Socialism, but it highlights the fact that Heidegger cannot be read independently of his political views. In Black Notebooks, Heidegger associates the spirit of calculation of modern age with the Jewish worldview. The growing rootlessness of the modern age can only be countered through the conception of the 'homeland' rooted in

\footnotetext{
${ }^{34}$ Martin Heidegger, "The Self-Assertion of the German University," trans. by William S. Lewis, in The Heidegger Controversy: A Critical Reader, 29-39.

${ }^{35}$ Ibid., 38.

(c) 2016 Saurabh Todariya

http://www.kritike.org/journal/issue 18/todariya june2016.pdf

ISSN 1908-7330
}

(c) BY-NC-ND 
German tradition and language. Heidegger hoped to overcome the rootlessness of the modern age or the inauthenticity of Dasman through invoking the community, which would ground itself in the historicity. ${ }^{36}$

The usage of these terms suggests that the resoluteness of Dasein in Being and Time is not merely a formal category but has to be understood in the context of National Socialism. The kind of meaning Heidegger gives to these terms while supporting National Socialism clearly shows the political implications of these terms, which Heidegger may have had in his mind while writing Being and Time. It can be argued that in Being and Time, Heidegger must be looking up to National Socialism as a kind of a historical possibility by which Germany could realize its historical mission. That is why the question of Repetition holds so much importance for a resolute Dasein in Being and Time. Heidegger defines Repetition as the historical possibilities, which have been there but were not actualized. In the light of the Rectoral address, we can say that Heidegger must have seen in the National Socialist movement the possibility of Repetition of the historical destiny of the German nation. It is true that Heidegger soon got disenchanted with the National Socialism and its policy of racism, and he resigned from the rectorship after one year. Yet his sympathy for the National Socialism remained unabated as it is evident from his lectures Introduction to Metaphysics. In these lectures, Heidegger while discussing the question of Being, makes reference to the 'inner greatness' of the National Socialism. He analyzes the condition of Germany with reference to the ideologies prevalent at that time. According to him, on the one hand, there is USSR and its communism. On the other, there is USA and its consumerism. Heidegger was contemptuous of both of these alternatives and made the case for a third alternative, which is only possible by understanding the great cultural and spiritual wealth of Germany.

Our people, as standing in the center, suffer the most intense pressure-our people, the people richest in neighbors and hence the most endangered people, and for all that, the metaphysical people. We are sure of this vocation; but this people will gain a fate from its vocation only when it creates in itself a resonance, a possibility of resonance for this vocation, and grasps its tradition creatively. All this implies that this people, as a historical people, must transpose itself-and with it the

${ }^{36}$ For the discussion on Black Notebooks and Heidegger's anti-Semitism, see Jesús Adrián Escudero, "Heidegger's Black Notebooks and the Question of Anti-Semitism," in Gatherings: The Heidegger Circle Annual, 5 (2015), 21-49.

(c) 2016 Saurabh Todariya

http://www.kritike.org/journal/issue 18/todariya june2016.pdf

ISSN 1908-7330 
history of the west-from the center of their future happening into the originary realm of the powers of Being. ${ }^{37}$

In various reflections on Black Notebooks, the issue of Germany remains a central question where Heidegger repeatedly asks the question "who are we?" Heidegger time and again gets back to the question of historicity and culture which defines the essence of Dasein. In Black Notebooks, Heidegger differentiates between Germans and Jews on the basis of their homeland and groundlessness. Germans are rooted in their homeland (Heimatland) and their native soil (Vaterland), while Jews are characterized by diaspora, migration, and exodus, which Heidegger calls as groundlessness (Bodenlosigkeit). The urban and ungrounded way of Jewish life represents a danger for the people's community. The homeland can only be secured by reconnecting with the German culture and tradition and Heidegger saw this possibility in National Socialism. ${ }^{38}$

The question of Being in Heidegger, therefore, seems to point towards the historical struggle with which Dasein or more aptly German Dasein is engaged. Heidegger's notion of historicity suggests that the true essence of Germany can only be realized through this struggle. In this struggle, the idea of Repetition connects the individual fate with the destiny of the community and he is able to relate with the historicality in an authentic manner.

\section{Dasein and Violence}

Heidegger defines struggle or violence as an essential feature of Dasein through the analysis of the Greek Tragedy Antigone. Heidegger argues that human beings are uncanny in nature and they are capable of doing utmost violence and, thereby, capable of changing the established courses and only in this strife the 'political' is born. Because of being uncanny, humans run against the limits imposed on them. According to Heidegger, the notion of political could be understood only with reference to this struggle. Hence, the fundamental essence of humans is to be apolis, that is, to run against the limits imposed by the State. Heidegger shows it through the character of Antigone. Antigone defies the order of the King who decrees that her brother should not be given burial as he waged the war against the State. According to Heidegger, the defiant act of Antigone shows the true nature of

\footnotetext{
${ }^{37}$ Martin Heidegger, Introduction to Metaphysics, trans. by Gregory Fried and Richard Polt (New Haven: Yale University Press, 2000), 41.

${ }^{38}$ Escudero analyzes Black Notebook's anti-semitism and the idea of Historicity in Being and Time by taking into account the notion of Destiny in Heidegger. See Escudero, "Heidegger's Black Notebooks and the Question of Anti-Semitism."

(c) 2016 Saurabh Todariya http://www.kritike.org/journal/issue 18/todariya june2016.pdf ISSN 1908-7330
}

(c) $)$ BY-NC-ND 
humans as deinon, which is basically going against the limits imposed on it by using violence. This violence is not physical violence but the violation of the limits imposed by the polis.

Every violent taming of the violent is either victory or defeat. Both throw one out of the homely, each in a different way, and they first unfold, each in a different way, the dangerousness of the Being that has been won or lost ... The one who is violence-doing, the creative one, who sets out into the un-said, who breaks into the un-thought, who compels what has never happened and makes appear what is unseen, this violence-doing one stands at all times in daring. ${ }^{39}$

The 'violence' inherent in Dasein struggles with the established political course and makes it uncanny or uncomfortable with the established political ethos. We can connect it with the notion of authenticity developed by Heidegger in Being and Time. Authenticity also involves a kind of struggle with the established norms of Dasman. This is evident when we analyze the authenticity of Dasein with respect to the community. Authenticity requires that one should be resolute to decide for oneself, not as one feels or desires but with respect to the historical possibilities one has inherited. Only by 'repeating' the past can one own up the history in an authentic manner. Hence, the authenticity of the existence demands that Dasein has to take into account the historicity in which it is fallen and has to rescue itself from being leveled down by the inauthentic life of Dasman. Heidegger saw the possibility of authenticity in National Socialism and felt that it would let the true essence of the people emerge. Dasein has to become resolute in order to actualize this historical possibility. ${ }^{40}$

Dasein can either slip back into Dasman or become resolute. However, as we have discussed earlier, this resoluteness does not make Dasein solipsistic but rather makes him realize that its individual fate is inextricably linked with the destiny of its community. Dasein, therefore, becomes resolute by relating to the existence in an authentic manner. Although Heidegger differentiates between existential and existentiell aspects, he does not reduce resoluteness into some definite resolve. Therefore,

${ }^{39}$ Heidegger, Introduction to Metaphysics, 172.

${ }^{40}$ Ricahrd Wolin argues that the idea of authenticity in Being and Time totally dispenses with the richness of everyday life. The usage of 'call of conscience', 'reticence' makes the authenticity so mysterious that it could not be translated into the everyday, ontic life. See Richard Wolin, The Politics of Being: The Political Thought of Martin Heidegger (New York: Columbia University Press, 1990).

(c) 2016 Saurabh Todariya

http://www.kritike.org/journal/issue 18/todariya june2016.pdf

ISSN 1908-7330 


\section{AUTHENTIC HISTORICALITY AND NATIONAL SOCIALISM}

resoluteness remains like an empty rule, devoid of content. Heidegger does not prescribe what kinds of actions are resolute or irresolute. Hence, resoluteness remains at the formal level. In order to give existentiell form to this existential category, Dasein has to decide on the singularity of its historical situation.

This authentic Dasein can only relate to the community in an authentic way. However, Heidegger gives this existential interpretation a somewhat existentiell dimension by introducing the notion of Repetition. Repetition gives a particular direction to the resoluteness that it has to realize the possibilities, which have been there in the past. Although open to ethical interpretation, the notion of Repetition runs into trouble when we analyze it in the light of Heidegger's sympathy for National Socialism. Heidegger, in many of his writings, has remained obsessed with German culture and hoped for the realization of the German essence. In his Rectoral Speech, he calls Nietzsche and not Edmund Husserl as the last German philosopher, which shows his narrow notion of Germany. ${ }^{41}$ Hence, it is difficult to assume that the notion of Repetition or destruction of tradition in Heidegger's scheme would result in a more comprehensive approach. Heidegger's ontology sought to find out the essence of man and culminates in the German man. It does not mean that Heidegger's thoughts can be reduced to Nazi ideology and that he should be treated as a Nazi ideologue. Heidegger, in his thoughts and actions, remained distant from the crude Nazi ideology and its official biologism. However, his temptation to National Socialism is the failure of understanding it as the historical possibility which can fulfill the 'spiritual mission' of the Nation. Even after the debacle of Germany in Second World War, Heidegger retained his fondness for German poets and the exclusive greatness of German language. It seems that 'thinking' can take place only in the German or Greek language ${ }^{42}$ and via the German poets or Greek thinkers. ${ }^{43}$

\footnotetext{
${ }^{41}$ Martin Heidegger, "The Self- Assertion of the German University," 33.

${ }^{42}$ In response to the question of whether he believes that Germans have a special task, he responds - "I am thinking of the special inner kinship between the German language and the language of the Greeks and their thought. This is something that the French confirm for me again and again today. When they begin to think, they speak German. They assure [me] that they do not succeed with their own language." Martin Heidegger, “Only a God Can Save Us: Der Spiegel's Interview with Martin Heidegger (1966)," trans. by Maria D. Alter and John Caputo, in The Heidegger Controversy: A Critical Reader, 91-116.

43 Alain Badiou criticizes Heidegger's constant reference to the German poets like Trakl and Holderlin by calling it as poetic ontology, haunted by the loss of origin. See Alain Badiou, Being and Event, trans. by Oliver Feltham (London: Bloomsbury, 2013), 10.
}

(c) 2016 Saurabh Todariya http://www.kritike.org/journal/issue 18/todariya june2016.pdf ISSN 1908-7330 


\section{Concluding Remarks}

To conclude the paper, we can say that the notion of Geschistlichkeit in Being and Time should be understood from the perspective of authenticity. Heidegger's emphasis on authentic existence is basically the attempt to find the meaning of existence which remains forgotten in the everyday inauthentic life. Heidegger's differentiation between the authentic and inauthentic level of existence is based on Dasein's capacity to individuate itself from the everyday world of Dasman. According to Heidegger, the everyday world of Dasman reduces Dasein into the 'nameless and faceless' entity where everyone can replace anyone. However, this tranquil world of Dasman is broken by anxiety which individuates Dasein by jamming the comportment towards the entities. Only a 'resolute' Dasein, who is ready to face anxiety, can connect itself with the idea of 'authentic historicality.' The notion of 'authentic historicality' in Heidegger highlights the importance of the past in terms of living tradition, which affects humans. However, the idea of authentic historicality in Being and Time also shows that Heidegger's thinking, despite its radical nature, remains captive to the nostalgia for the German nation and culture. Heidegger's thoughts, while claiming to be formal, in some way or another still responds to the situation of Germany of that time. Heidegger's notion of authentic historicality, therefore, could not be studied independently of its political implications, which are evident from the analysis of the concept of Repetition and Destiny in Being and Time. Heidegger's analysis of 'authentic historicality,' therefore, presents before us a curious mixture of fundamental ontology and conservative politics.

Centre for Philosophy, Jawaharlal Nehru University, India

\section{References}

Adorno, Theodor, The Jargon of Authenticity, trans. by Knut Tarnowski and Frederic Will (Evanston: NorthWestern University Press, 1973).

Arendt, Hannah. Responsibility and Judgment (New York: Schocken Books, 2003).

Badiou, Alain, Being and Event trans. by Oliver Feltham (London: Bloomsbury, 2013).

Caputo, John, Radical Hermeneutics: Repetition, Deconstruction and the Hermeneutics (Bloomington: Indiana University Press, 1987).

Derrida, Jacques, Of Spirit: Heidegger and the Question, trans. by Geoffrey Benington and Rachel Bowlby (Chicago: The University of Chicago Press, 1989). 


\section{AUTHENTIC HISTORICALITY AND NATIONAL SOCIALISM}

Escudero, Jesús Adrián, “Heidegger's Black Notebooks and the Question of Anti-Semitism," in Gatherings: The Heidegger Circle Annual, 5 (2015).

Habermas, Jurgen, "Martin Heidegger: On the Publication of the Lectures of 1935," trans. by William S. Lewis, in The Heidegger Controversy: A Critical Reader (Cambridge: The MIT Press, 1993).

Heidegger, Martin, Being and Time, trans. by John Macquarrie and Edward Robinson (New York: Harper and Row, 1962). Introduction to Metaphysics, trans. by Gregory Fried and Richard Polt (New Haven: Yale University Press, 2000). "Only a God Can Save Us: Der Spiegel's Interview with Martin Heidegger (1966)," trans. by Maria D. Alter and John Caputo, in The Heidegger Controversy: A Critical Reader (Cambridge: The MIT Press, 1993).

"The Self-Assertion of the German University," trans. by William S. Lewis, in The Heidegger Controversy: A Critical Reader, ed. by Richard Wolin (Cambridge, The MIT Press, 1993).

The Question Concerning Technology and Other Essays (New York: HarperCollins, 1982).

Levinas, Emmanuel, Totality and Infinity, trans. by Alpohnso Lingis (Hague: Martinus Nijhoff Publishers, 1969).

Lyotard, Jean-Francois, Heidegger and "the jews", trans. by Andreas Michel and Mark S. Roberts (Minneapolis: University of Minnesota Press, 1990).

Ricouer, Paul, Time and Narrative, vol. 3, trans. by Kathleen Blamey and David Pellauer (Chicago: The University of Chicago Press, 1988).

Steigler, Bernard, Technics and Time, vol. 1, trans. by Richard Beardsworth and George Collins (Stanford California: Stanford University Press, 1998).

Villa, Dana, Arendt and Heidegger: The Fate of the Political (Princeton: Princeton University Press, 1996).

Wolin, Richard, ed. The Heidegger Controversy: A Critical Reader (Cambridge: MIT Press, 1993).

Wolin, Richard, The Politics of Being: The Political Thought of Martin Heidegger (New York: Columbia University Press, 1990).

(c) 2016 Saurabh Todariya http://www.kritike.org/journal/issue 18/todariya june2016.pdf ISSN 1908-7330 